\title{
MARKET DEMAND AND SUPPLY OF Cordia millenii (OMỌ) SAWNWOOD AND ITS EFFECT ON CONSERVATION OF THE SPECIES
}

\author{
Oyinlola Abiodun FASORO, Department of Social and Environmental Forestry, University of Ibadan, Nigeria, \\ oyinlola4christ@gmail.com; oa.fasoro@ui.edu.ng (corresponding author) \\ Opeyemi Isaac AJEWOLE, Department of Social and Environmental Forestry, University of Ibadan, Nigeria, \\ dropeajewole@gmail.com \\ Adeola Omobolanle ADENIRAN, Department of Social and Environmental Forestry, University of Ibadan, Nigeria, \\ adeolaadeniran122@gmail.com
}

This study examined market demand and supply of Cordia millenii (Ọmọ) Sawnwood in Bodija sawnwood market so that stakeholders involved in the economies of the sawnwood will make appropriate economic decisions thereby ensuring sustainable utilization of the species. Bodija sawnwood market is made up of nine zones comprising 66 blocks and 1868 stalls. Five zones were purposively selected based on the abundance of Omọ sawnwood marketers in the zones. Simple random sampling was then used to select 40 respondents in each zone. Structured questionnaires were used and data obtained were analyzed using descriptive statistics. Respondents (89.5\%) were male, $75 \%$ were between the ages of 30 and 49 years, $97 \%$ had formal education and $70.5 \%$ had been involved in the sawnwood trade between 10 to 29 years. Respondents $(96.5 \%)$ stated that there has been a steady increase in the market demand and supply of the sawnwood over the years. Respondents $(85.5 \%)$ claimed timber were gotten from government forest plantations. Strength (37.5\%), hardness (15\%), durability (26.5\%) and appearance $(21 \%)$ were identified as the major attributes influencing market demand of the sawnwood. High demand by consumers (76\%) and season (23\%) were factors influencing the market supply of the sawnwood. Poor infrastructure and unreliable institutional mechanisms (31\%) were identified as challenges encountered. Market demand and supply of the sawnwood has been on the increase due to its ubiquitous nature. It is therefore recommended that forestry stakeholders should make a deliberate effort in the sustainable conservation of indigenous tree species through afforestation and reforestation programmes.

Keywords: Sawnwood market, Trade, Cordia millenii (Omo), Sustainable, Stakeholders.

\section{INTRODUCTION}

Chamshama and Nwonwu (2004) reported that the major factors contributing to the reduction of forest cover in Africa's natural forests are the rapidly growing demand for wood for domestic uses, industries, export and wood fuel together with increasing demand for an array of non-wood forest products. Nigeria's natural forest in particular has been over-exploited without adequate conservation. The increased demand for forest resources, particularly timber, has driven forest exploitation to an unsustainable rate in the country. FAO (2003) affirmed that urbanization, industrialization and above all, human population growth are factors contributing to this depletion.

Studies have also shown that many indigenous tree species are going into extinction as a result of their multipurpose benefits. Cordia millenii (Omọ) which is an indigenous tree species is not left out due to its ubiquitous nature. Cordia millenii (West African Cordia, Nigeria: Omọ) is a valuable West African timber tree species with good timber quality. The species contain about 300 species of shrubs and trees that are found worldwide, mostly in warmer regions. It occurs in closed forests and secondary formation, it regenerates well after disturbance. The species is known to be widely dispersed in tropical Africa. They are found in Uganda, Ghana, Congo, Nigeria, Ivory Coast, W. Cameroons, Angola, Central African Republic, Gabon, Guinea, Kenya, Sudan and Tanzania. Cordia millenii is a genus of flowering plants in the borage family (Boraginaceae). The common names of Cordia millenii include West African Cordia, English drum tree, Nigeria: Omọ, Cameroon: Ebe (African Regional Workshop, 1998).

FAO (1999) and Arowosoge et al. (2011) reported that sawnwood has the highest production and demand among all forestry products in Nigeria and the demand is estimated at $200,000 \mathrm{~m}^{3}$ per annum. Aiyeloja et al. (2013) stated that logs are processed into planks/sawnwood of different sizes in sawmills for distribution and marketing. Cordia millenii (Ọmọ) which is a multipurpose tree species is used across the country and its prices are a fundamental prerequisite for the socioeconomic development of the country. Cordia millenii (Omọ) logs are processed into sawnwoods and the natural beauty of Cordia millenii (Omọ) sawnwood lies in its inherent characteristics such as appearances, colours, knots, durability, strength, hardness, mineral streaks and so on (Panshin et al., 1962).

Copyright () 2021 The Authors. Published by Vytautas Magnus University. This is an open-access article distributed under the terms of the Creative Commons Attribution License (CC BY 4.0), which permits unrestricted use, distribution, and reproduction in any medium, provided the original author and source are credited. 
Sawnwood business is a relatively large pool of jobs where many people derive their income for sustainable and healthy living. Thus, sustainable conservation and utilization of this species can yield returns for the sawnwood marketers to meet their financial needs and improve their livelihood and wellbeing.

Prestemon and Abt (2002) stated that demand is the schedule of the quantities that would be purchased by consumers over a range of prices while supply is the schedule of quantities that would be produced in a geographic region by product manufacturers over a range of prices. Therefore, the demand and supply of Cordia millenii (Omọ) sawnwood is the quantities produced and quantities that will be purchased at a particular price. However, FAO (1999) reported that the efficiency of the marketing process as a link between the producer and the consumer is a major determinant of the price, quantity etc. of demand and supply of forestry products (e.g. timber). Thus, this affects the consumption pattern of sawnwood due to its imperfect and inefficient nature of sawnwood marketing.

Therefore, sawnwood market demand and supply does not end in the knowledge of the quantities of sawnwood in the market but also the sources of the sawnwood, the rate of flow of products and the relationship between its supply and demand. In Nigeria, investigation into the economies of Cordia millenii (Ọmọ) sawnwood is remarkably trivial, little or no research has been carried out on the flow (rate of production and consumption) of Cordia millenii (Ọmọ) sawnwood. Therefore, this study assessed market demand and supply of Cordia millenii (Ọmọ) sawnwood to promote sustainable utilization of Cordia millenii (Ọmọ).

\section{METHODOLOGY}

\section{Study area}

Ibadan covers a total area of $3,080 \mathrm{~km}^{2}$. The ancient city is the capital and most populous city of Oyo State, Nigeria. It lies between Latitudes $7^{\circ} 20^{\prime} 03^{\prime \prime} \mathrm{N}$ and $7^{\circ} 26^{\prime} 12^{\prime \prime} \mathrm{N}$ and Longitudes $3^{\circ} 50^{\prime} 65^{\prime \prime} \mathrm{E}$ and $3^{\circ} 57^{\prime} 48^{\prime \prime} \mathrm{E}$. Ibadan is located in southwestern Nigeria and at about $119 \mathrm{~km}$ (74 miles) northeast of Lagos and $120 \mathrm{~km}$ (75 miles) east of the Nigerian international border with the Republic of Benin. It lies completely within the tropical forest zone but close to the boundary between the forest and the derived savanna. The city ranges in elevation from $150 \mathrm{~m}$ in the valley area to $275 \mathrm{~m}$ above sea level on the major north-south ridge which crosses the central part of the city.

\section{Bodija sawnwood market, Ibadan}

Bodija market is located in Ibadan North Local Government Area of Oyo State, Nigeria. It was established in the year 1970. The market is about one kilometre away from the University of Ibadan and it is along the road to the State Government's Secretariat which is also about one kilometre away (Filani, 2005). Bodija market lies between Latitudes $7^{\circ} 25^{\prime} 52^{\prime \prime} \mathrm{N}$ and $7^{\circ}$ $26^{\prime} 22^{\prime \prime} \mathrm{N}$ and Longitudes $3^{\circ} 54^{\prime} 36^{\prime \prime} \mathrm{E}$ and $3^{\circ} 55^{\prime} 12^{\prime \prime} \mathrm{E}$, while the sawnwood market is located between Latitudes $7^{\circ} 26^{\prime} 20^{\prime \prime}$ $\mathrm{N}$ and $7^{\circ} 26^{\prime} 16^{\prime \prime} \mathrm{N}$ and Longitudes $3^{\circ} 54^{\prime} 56^{\prime \prime} \mathrm{E}$ and $3^{\circ} 55^{\prime} 12^{\prime \prime} \mathrm{E}$ (Ajewole and Fasoro, 2013). The sawnwood market covers 0.12 square $\mathrm{km}$ out of the 0.48 square $\mathrm{km}$ of the entire Bodija Market (Ajewole and Fasoro, 2013).

There are 25 sawnwood markets in Ibadan metropolis, however, Bodija Sawnwood Market is the biggest Sawnwood market in the Southwestern geopolitical zone of Nigeria. It is also the headquarters of Sawnwood Marketers Association of Oyo state.

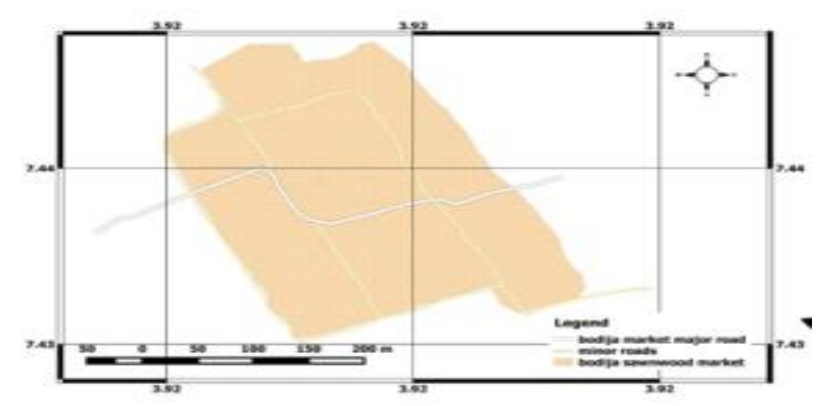

Figure 1. Map of Bodija Sawnwood Market, Ibadan showing the Plank Market

\section{Method of data collection and analytical techniques}

Bodija Sawnwood Market consist of nine zones, with an average of about 1,000 plank sellers in total. Purposive sampling was used to select 5 zones that were identified to be prevalent with the Cordia millenii (Omọ) sawnwood. Simple Random Sampling was then used to select 40 Cordia millenii (Ọmọ) sawnwood marketers. Thus, making a total of 200 Cordia millenii (Ọmọ) sawnwood marketers. Primary data used for the study were obtained through the administration of a structured questionnaire. Data were analyzed using descriptive statistics.

Questionnaires were administered to respondents on December, 2019. Some of the research questions were the demographic characteristics of Cordia millenii (Ọmọ) sawnwood marketers; sources and sites of Cordia millenii (Ọmọ), the number of years in business, regularity of sales and purchases, factors influencing supply and demand of Cordia millenii (Ọmọ) sawnwood in the market and major challenges faced as Cordia millenii (Ọmọ) sawnwood marketer. 


\section{RESULTS}

\section{Socio-economic characteristics of Cordia Millenii (Omo) sawnwood marketers}

The results in Table 1 show the distribution of sawnwood marketers based on socioeconomic variables. From the table, $89.5 \%$ were male, $75 \%$ fell between the age range of 30 and 49 years and $99 \%$ belongs to the Yoruba Ethnic group. Also, $65 \%$ of the respondents had secondary education, $20 \%$ had primary education, $12 \%$ had tertiary education and very few $(3 \%)$ had no formal education. Moreover, $70.5 \%$ of the respondents have been involved in sawnwood trade between 10 to 29 years.

Table 1. Frequency distribution of socio-economic characteristics of respondents

\begin{tabular}{llll}
\hline Demographic characteristics & & Frequency $(\mathrm{n}=200)$ & Percentage $(\%)$ \\
\hline Sex & Male & 179 & 89.5 \\
& Female & 21 & 10.5 \\
Age & $<30$ & 15 & 7.5 \\
& $30-39$ & 46 & 23.5 \\
& $40-49$ & 103 & 51.5 \\
& $50-59$ & 27 & 13.5 \\
Education & 60 and above & 9 & 4.5 \\
& No formal education & 6 & 3.0 \\
& Primary Education & 40 & 20.0 \\
Ethnicity & Secondary Education & 130 & 65.0 \\
& Tertiary Education & 24 & 12.0 \\
Number of Years in Sawnwood Trade & Yoruba & 198 & 99.0 \\
& Igbo & 2 & 1.0 \\
& $<10$ & 27 & 13.5 \\
& $10-19$ & 76 & 38.0 \\
& $20-29$ & 65 & 32.5 \\
\end{tabular}

\section{Sources and sites where Cordia millenii (Ọmo) sawnwood were acquired}

Sawnwood is a natural product from the forests which is often sorted out into various categories for efficient end uses. However, round logs are first harvested from the forest before been processed or sorted into sawnwood. Thus, Table 2 reveals that respondents claimed Cordia millenii (Omọ) wood species were sourced from outside Oyo state. The respondents iterated that the species were gotten from Ogun, Osun, Ekiti and Ondo, Kogi, Edo and Kwara States. Respondents (60.5\%) stated that Cordia millenii (Omọ) were sourced from the Southwestern part of the country (Ogun, Osun, Ekiti and Ondo). The table also shows that $17.5 \%$ of the respondents obtained Cordia millenii (Omọ) from Kogi State, $15 \%$ of the respondents got the species from Edo State while $7 \%$ of the respondents sourced for the species in Kwara State.

Furthermore, Table 2 reveals that $85.5 \%$ of the respondents claimed Cordia millenii (Ọmọ) round logs were gotten from Government-Owned Forest Plantations, 14\% of respondents claimed logs were gotten from Forest Reserves and a negligible part $(0.5 \%)$ reported that the logs were gotten from Free Zones.

Table 2. Frequency distribution of Cordia millenii sources and sites

\begin{tabular}{llll}
\hline & States & Frequency & Percentage \\
\hline Source & Ogun & 38 & 19 \\
& Ondo & 36 & 18 \\
Osun & 26 & 13 \\
Edo & 30 & 15 \\
Kwara & 14 & 7 \\
Kogi & 35 & 17.5 \\
& Ekiti & 21 & 10.5 \\
Total & 200 & 100.0 \\
\hline Locations & Frequency & Percentage \\
\hline Sites & Free Zones & 1 & 0.5 \\
& Government Plantation & 171 & 85.5 \\
& Forest Reserves & 28 & 14.0 \\
& Total & 200 & 100.0 \\
\hline
\end{tabular}

Increase in demand and supply of Cordia millenii (Ọm) sawnwood in Bodija sawnwood market

Table 3 shows that $96.5 \%$ of Cordia millenii (Ọmọ) sawnwood marketers claimed that there has been a consistent increase in the market demand and supply of Cordia millenii (Omọ) sawnwood over the years. As the demand for Cordia millenii (Ọọ) by consumers increases so also the supply of the product into the market increases. Thus, there has been a steady increase in the flow of Cordia millenii sawnwood in the Market. 
Table 3. Frequency distribution of the flow of market demand and supply of Cordia millenii (Omọ) sawnwood

\begin{tabular}{lll}
\hline Increase in Demand & Frequency & Percentage $(\%)$ \\
\hline Yes & 193 & 96.5 \\
No & 7 & 3.5 \\
Total & 200 & 100.0 \\
\hline
\end{tabular}

Factors influencing market demand Cordia Millenii (Ọmọ) sawnwood

The choice of wood species for a particular purpose or utilization potentials varies as a result of different features and characteristics of the wood. Some of these features include wood strength, natural durability, colour (appearance), ease of machine and workability, cost of construction, hardness and availability. Thus, Table 4 reveals that $37.5 \%$ of the respondents identified strength as the main reason the species is in relatively high demand, $15 \%$ of respondents identified hardness as the reason for the increase in demand, $26.5 \%$ of respondents identified the species durability, while $21 \%$ respondents identified appearance as the main reason for higher demand of the species in the market.

Table 4. Distribution of factors influencing market demand of Cordia Millenii (Ọmọ) Sawnwood

\begin{tabular}{lll}
\hline Factors & Frequency $(\mathrm{n}=200)$ & Percentage $(\%)$ \\
\hline Strength & 75 & 37.5 \\
Hardness & 30 & 15.0 \\
Durability & 53 & 26.5 \\
Appearance & 42 & 21.0 \\
Total & 200 & 100 \\
\hline
\end{tabular}

\section{Factors influencing market supply Cordia Millenii (Ọmọ) sawnwood}

Table 5 reveals the factors influencing the supply of Cordia millenii (Omọ) sawnwood into the market. From Table $5,76 \%$ of the respondents reported that high demand by consumers influences the market supply of Cordia millenii (Omọ) sawnwood, $23 \%$ respondents claimed season (dry or wet) determines market supply while a negligible part of the respondents (1\%) stated that availability of the species in the forest influence the supply into Bodija market.

Table 5. Distribution of factors influencing the market supply of Cordia millenii (Ọọ) Sawnwood

\begin{tabular}{lll}
\hline Factors & Frequency $(\mathrm{n}=200)$ & Percentage $(\%)$ \\
\hline High demand by consumers & 152 & 76.0 \\
Season & 46 & 23.0 \\
Availability & 2 & 1.0 \\
Total & 200 & 100 \\
\hline
\end{tabular}

\section{Supply regularity of Cordia Millenii (Omo) sawnwood}

From Table 6 , results show that $53.5 \%$ of the marketers get their supplies weekly, $42.5 \%$ of the marketers get deliveries fortnightly and $4.0 \%$ of the marketers get Cordia millenii (Omọ) sawnwood supply monthly. However, marketers stated that the regularity of Cordia millenii (Omọ) sawnwood sometimes depend on the aforementioned factors influencing market supply and demand.

Table 6. Distribution of Cordia millenii (Ọmọ) supply regularity

\begin{tabular}{lll}
\hline Regularity & Frequency $(\mathrm{n}=200)$ & Percentage $(\%)$ \\
\hline Monthly & 8 & 4.0 \\
Fortnightly & 85 & 42.5 \\
Weekly & 107 & 53.5 \\
Total & 200 & 100 \\
\hline
\end{tabular}

\section{Challenges facing Cordia millenii sawnwood (omo) business}

Table 7 shows that many respondents identified more than one challenge affecting the marketing of Cordia millenii sawnwood (omo). Table 7 reveals that $31.0 \%$ of the respondents indicated that lack of infrastructure and unreliable institutional mechanisms, $18.0 \%$ of the respondents claimed lack of finance and poor infrastructure and $12.0 \%$ of the respondents stated that lack of finance and unreliable institutional mechanisms are the major challenges encountered as Cordia millenii sawnwood (omo) marketers. Also, 15.5\%, 11.0\%, 8.5\% and 4.0\% of the respondents claimed unreliable institutional mechanisms, lack of finance, poor infrastructure and species scarcity and competition are the major challenges affecting Cordia millenii sawnwood (omo) marketing.

Table 7. Frequency distribution of challenges faced by respondents in marketing Cordia millenii sawnwood (omo)

\begin{tabular}{lll}
\hline Challenges & Frequency & Percentage $(\%)$ \\
\hline Lack of finance & 22 & 11.0 \\
Unreliable institutional mechanisms & 31 & 15.5 \\
Poor infrastructure & 17 & 8.5 \\
Species scarcity and competition & 8 & 4.0 \\
Lack of finance and unreliable institutional mechanisms & 24 & 12.0 \\
Lack of financial and poor infrastructure & 36 & 18.0 \\
Poor infrastructure and unreliable institutional mechanisms & 62 & 31.0 \\
Total & 200 & 100 \\
\hline
\end{tabular}




\section{DISCUSSION}

\section{Socio-economic characteristics of respondents}

The results show that the business is dominated by males. There is a differentiating line when it comes to gender marketing Cordia millenii sawnwood (omo). This gender difference may be attributed to the tedious nature of sorting, grading, carrying and arranging sawnwood which require lots of energy. However, Table 1 shows that $10.5 \%$ of the respondents were female, which shows that sawnwood marketing is gender-friendly and there shouldn't be a gendered division of labour, that is, women should not be limited to certain roles, positions and tasks when it comes to forest activities and development. This is similar to the submission of Ajewole and Fasoro (2013) that although forestry-related activities are dominated by men due to the perception that the activities are time-consuming and strenuous, nonetheless, the study affirmed that sawnwood marketing is gender-friendly and should not be connected to masculine or feminine qualities of individuals.

The age group of 30-49 years which was the modal age group of the respondents is the age group in which people are saddled with various responsibilities. Respondents in this age group can be referred to young middle-class citizens with attendant pressures from families and friends. Thus, they have the strength and vigour to perform various activities required to generate income to improve their livelihood and reduce poverty.

The study revealed that $97 \%$ of the respondents had formal education and the highest level of education possessed by most of the respondents is the West Africa Senior School Certificate (WASSC). Education is known to facilitate peoples understanding and the use of improved technology and practices. This means the higher the level of education of an individual, the more likely an individual is willing to accept new methods of marketing and management, try new ideas and be more willing to participate in sustainable forest development. This means education will help sawnwood marketers to carry out their daily activities such as dissemination of information to consumers and suppliers, record keeping and management of the business efficiently. Oladele et al. (2013) affirmed that in businesses, educational status affects skill acquisition and bookkeeping positively.

Respondents $(70.5 \%)$ stated that they have been in the business for between 10 and 29 years. This shows that sawnwood marketing is a lucrative business that can sustain the livelihood and wellbeing of marketers. Ajewole and Fasoro (2013) stated that the number of years of sawnwood traders' experience can also be an indirect measure of the authenticity and reliability of the information gathered from the traders because such information is based on the firsthand experience. Thus, sawnwood marketing can be said to be a business that can stand the test of time and sustainability cater for the wellbeing of those involved.

\section{Examination of Market Demand and Supply of Cordia millenii (Ọmọ) Sawnwood}

Table 3 revealed that most of the respondents (96.5\%) stated that the market demand and supply of Cordia millenii (Omọ) has been on the increase. This report is similar to Ajewole et al. (2016) report which stated that in Nigeria, Cordia millenii (Omọ) sawnwood is the $4^{\text {th }}$ most preferred sawnwood after Gmelina arborea, Khaya spp and Tectona grandis respectively, thus, there is a growing increase in its demand and supply.

Rowell (2005) stated that the utilization potentials or the choice of wood species for a particular purpose vary due to these distinctive features and characteristics of an individual. Some of the features identified were strength, natural durability, colour (appearance), ease of machine and workability, cost of construction, hardness and availability of the wood species. Thus, the study revealed that the strength, hardness, durability and appearance of Cordia millenii (Omọ) sawnwood were identified by plank sellers as the factors influencing market demand.

The study showed that most of the respondents claimed high demand by consumers $(76 \%)$ determines the quantity of sawnwood supplied into Bodija market while $23.0 \%$ of the respondents attested that seasonal changes are of crucial importance among the factors that influence the supply of Cordia millenii (Omọ) sawnwood. Respondents claimed during the rainy season, forest terrain becomes extremely difficult to navigate by trucks, hence, this limits the quantity that will be available in the market. A negligible part of respondents (1.0\%) reported that the availability of Cordia millenii (Omọ) in the forest affects the supply of Cordia millenii (Omọ) sawnwood. This shows that when there is a limited number of Cordia millenii in forests or from their suppliers (timber contractors and sawmillers), there will be few Cordia millenii (Omọ) sawnwood in the market. Cerutti (2019) affirmed that sawnwood business is affected by seasonality. The study further stated that there are periods in which the demand for sawnwood is very high and periods when demand is very low depending on localized situations (rains, road conditions, etc.).

Table 6 shows that most of the respondents get the supply of Cordia millenii (Omọ) sawnwood weekly, some fortnightly and while others get supply monthly. However, respondents stated that supply regularity depends on demand by consumers, season and availability of species in the forest. For instance, if the demand for Cordia millenii (Omọ) sawnwood by consumers is very high, a sawnwood marketer might change from monthly supply to fortnight supply, also, if demand reduces, supply might change from weekly to a fortnight or monthly. In addition, some respondents iterated that it is not an unusual occurrence for Cordia millenii (Omọ) sawnwood to be sold in a day due to high demand, inherently, there won't be sales for the rest of the week until they get the next supply.

Further investigation reveals that the supply of Cordia millenii (Omọ) sawnwood in the study area is unpredictable during the rainy season. This confirms the report stated earlier that season affects the supply of Cordia millenii (Omọ) as forest terrain becomes extremely difficult for trunks during the rainy season. Thus, limiting the quantity of Cordia millenii (Omọ) sawnwood available in the market. Sawnwood marketers confirmed that January to March and October to December are the months when there is an easy and adequate flow of Cordia millenii (Omọ) sawnwood supply. 


\section{Challenges of sawnwood business}

Respondents mentioned quite many challenges faced in the business. Among all the challenges, financial (capital), institutional mechanisms (political instability, price fluctuation, unstable policies - taxes, duties and levies), infrastructure (transportation, storage and electricity), species scarcity and competition emerged as the most mentioned challenges by respondents.

The lack of capital and access to sources of capital are among the main constraints affecting sawnwood business as respondents stated that insufficient financial resources sometimes disallow them to build up stocks. This allows some marketers to make excess returns while others can lose more than warranted as those with financial muscles can build up stocks, inflate the price and sell to the uninformed consumer while others may underprice just to secure customers. Unstable policies (e.g. stumpage fees) also affect sawnwood business as there may be price inflation when some laws and regulations are made by the national government. Furthermore, lack of infrastructure facilities was identified as a constraint facing sawnwood business. Respondents stated that the routes and roads to extract timber from the forest are sometimes inaccessible and the situation is worst during the rainy season. Obsolete technology and archaic techniques in processing logs in sawmills were also stated to contribute to the shortage of planks as some planks may not be sawed into the desired thicknesses and width. They claimed lack of power supply increases the amount paid for log processing in the sawmills which eventually affect the price of planks. Sawnwood marketers also reported that lack of proper and modern storage facility in the market also affect their business. Few of the marketers who claimed they have the financial means of stock-building sawnwood affirmed that lack of storage facility discourages them from buying sawnwood in large quantities.

In addition, some respondents stated that sawnwood business is very competitive as there are many players, no coherent pricing policies, asymmetry of information, competition for inputs and also, the threat of substitution sometimes affects consumer's demand for sawnwood. Cerutti (ibid) affirmed that consumers preference for wood substitutes such as plastic, metal, wool, cotton, fabric, fibre, glass, steel, aluminium, brick, stone etc. may negatively have an impact on sawnwood business.

\section{CONCLUSION}

The study revealed that sawnwood marketing is gender-friendly, thus, there shouldn't be a gendered division of labour. According to the study, there has been a steady increase in the demand and supply of Cordia millenii sawnwood in the market, implying that the pressure on forests will continue to rise. To increase wood supply and reduce pressure on natural forests, the government and stakeholders should make a concerted effort to conserve indigenous tree species through regular afforestation and reforestation. Private forestry and the establishment of forest plantations for specific end uses are among the goals of Nigeria's National Forest Policy. As a result, all forest stakeholders (timber contractors, sawnwood marketers, Forestry Ministries, Departments, and Agencies (MDAs), etc.) must collaborate with Nigeria's apex body (Forestry Association of Nigeria) to liaise with the government to formulate appropriate policies and strategies that will facilitate reforestation and afforestation, as well as establish a Marketing Information System for sawnwood to collect, store, analyze, and make available data to stakeholders on various aspects of the market and marketing of sawnwood.

\section{REFERENCES}

1. African Regional Workshop. 1998. Cordia millenii: The IUCN Red List of Threatened Species 1998: T33042A9752688. https://doi.org/10.2305/IUCN.UK.1998.RLTS.T33042A9752688.en

2. Aiyeloja A. A, Oladele A. T. Furo S.B. 2013. Sustaining Livelihood through Sawn Wood Marketing in Port Harcourt, Nigeria.

3. Ajewole O. I., Fasoro O. 2013. Market and marketing information of Bodija plank market in Ibadan metropolis, Ibadan, Oyo State, Nigeria. Nigerian Journal of Forestry, Vol. 43(1) pp. 13-19.

4. Ajewole O. I., Adedeji G. A., Olabisi W. B. 2016. Assessment of users' preferences for Sawn wood species in Ibadan metropolis, Nigeria. African Journal of Agriculture, Technology and Environment, Vol. 5(1), pp. 62-72.

5. Arowosoge O. G. E, Ogunsanwo O. Y., Popoola L. 2011. Spatial and Temporal Price Variations of Sawn Wood Utilized for Furniture Making in Selected Cities in Nigeria. Journal of Agriculture and Social Research (JASR), Vol. 11(1), pp. 106-117. https://doi.org/10.4314/jasr.v10i2.67539

6. Tsanga R., Ducenne Q., Habimana C., Brasseur R., Cerutti P.O. 2019. Wood Supply Chain in Rwanda: A Market Analysis. Technical Report. Available at https://www.researchgate.net/publication/342179005

7. Chamshama S., Nwonwu F. 2004. Plantation Forestry in Sub Saharan Africa: Silvicultural, Ecological and Economic Aspects.

8. FAO. 1999. Global Forest Products Consumption, Production, Trade and Prices: Global Forest Products model projections to 2010. FAO Forest Paper No. 81, 33 pp.

9. FAO. 2003. Forestry Outlook Study for Africa - African Forests: A View to 2020. African Development Bank, European Commission and the Food and Agriculture Organization of the United Nations Rome. Available at ftp://ftp.fao.org/docrep/fao/005/Y4526B/y4526b00.pdf

10. Filani M. O. 2005. Transport market study - the Bodija Cattle Market in Ibadan. Paper developed under a networked research programme funded by the UK Department for International Department.

11. OYO State. 2016. Available at http://www.oyostate.gov.ng/ 
12. Mungal A., Garbharran H. L. 2014. Cash Management Challenges of Small Businesses in a Developing Community. Mediterranean Journal of Social Sciences MCSER Publishing, Rome-Italy, Vol. 5, No. 27. https://doi.org/10.5901/mjss.2014.v5n27p11

13. Oladele A. T, Aiyeloja A. A., Aguma, Q. 2013. Economic Analysis of Cane Furniture Production in Rivers State, Nigeria. Journal of Economics and Sustainable Development, Vol. 4 (5), pp. 14-18.

14. Panshin A. J., Harrar E. S., Bethel J. S., Baker W. J. 1962. Forest Products, their Sources, Production, and Utilization. Ed. 2, pp. 538, Illus. New York : McGraw-Hill Book Co., Inc.

15. Prestemon J. P., Abt Robert C. 2002. Timber Products Supply and Demand.

16. Rowell R. M. 2005. Handbook of wood chemistry and wood composites. CRC Press, 200 N.W. Corporate Blvd., Boca Raton, Florida USA. https://doi.org/10.1201/9780203492437 